\title{
Enzyme linked direct antiglobulin tests in patients with autoimmune haemolysis
}

\author{
RJ SOKOL, S HEWITT, DJ BOOKER, R STAMPS \\ From the Regional Blood Transfusion Centre, Sheffield
}

SUMMARY Enzyme linked and agglutination direct antiglobulin tests were carried out on blood samples from 219 patients suspected of having autoimmune haemolysis. The enzyme linked tests were more sensitive: they could detect the small amounts of $\operatorname{IgG}, \operatorname{IgA}$, and $\operatorname{IgM}$ which are normally present on red cells and showed increased amounts of cell bound immunoglobulins in patients with Coombs test negative autoimmune haemolysis. Many patients had immunoglobulins of more than one class bound to their red cells; considering the degree of haemolysis in individual patients, it appeared that the different immunoglobulin classes acted synergistically in effecting red cell destruction, even in amounts too small to be detected by the agglutination tests. In patients with cold reacting autoantibodies and complement coating of the red cells active haemolysis was found (with one exception) where IgM was detected on the cells by the enzyme linked method. Elution studies indicated that immunoglobulins detected just by the enzyme linked techniques were red cell antibodies. Both enzyme linked and agglutination tests were negative in 66 patients: 61 of these had no evidence of haemolysis, and in the other five the haemolysis was not autoimmune in origin.

The detection of small amounts of erythrocyte bound immunogobulins is becoming increasingly important in investigating and monitoring the clinical progress of patients with autoimmune haemolysis.' To meet this need we require techniques that are more sensitive than the standard agglutination direct antiglobulin test (DAGT). This paper describes our preliminary experiences with an enzyme linked DAGT capable of detecting small amounts of $\operatorname{IgG}, \operatorname{IgA}$, and IgM on red cells and discusses the clinical importance of the findings.

\section{Material and methods}

During the investigation of 219 patients suspected of having autoimmune haemolysis ${ }^{2}$ both agglutination and enzyme linked DAGTs were performed on blood samples anticoagulated with potassium edetic acid.

The agglutination tests were carried out using monospecific anti-IgG, anti-IgA, anti-IgM, anti$\mathrm{C} 3 \mathrm{c}$, anti-C $3 \mathrm{~d}$, anti-C4, and broad spectrum antiglobulin reagents.

For the enzyme linked DAGTs $25 \%$ saline suspensions ( $\mathrm{vol} / \mathrm{vol})$ of washed patients' and pooled $\mathrm{O}$ cells (control) were incubated for one hour at $37^{\circ} \mathrm{C}$ with twice their volume of alkaline phosphatase

Accepted for publication 1 May 1985 linked anti-IgG, anti-IgA, and anti-IgM goat antihuman globulins (Sigma) diluted 1/50. After thorough washing the cells were added to p-nitrophenylphosphate substrate $(2 \mathrm{mg} / \mathrm{ml}$, buffered at $\mathrm{pH} \mathrm{9.88)} \mathrm{for} \mathrm{exactly} \mathrm{five} \mathrm{minutes} \mathrm{at} \mathrm{room}$ temperature. The specimens were quickly centrifuged, and the colour, which had developed in the supernatants, was measured at $405 \mathrm{~nm}$ using a Titertek Multiscan plate reader, further reaction having been inhibited by the addition of formalin. Initially, the tests were carried out in tubes as previously described, ${ }^{3}$ but later the method was adapted so that microtitre plates could be used. Results of tests were considered positive if their optical density exceeded that of the control pooled $\mathrm{O}$ cells by 0.2 ; previous studies with normal subjects had shown that an optical density of 0.2 was always more than 2.5 standard deviations greater than the mean.

\section{Results}

The patients were divided into five categories on the results of the DAGTs:

1 Sixty one patients in whom both agglutination and enzyme linked DAGTs were positive and detected the same immunoglobulin classes (Table 1). 2 Forty three patients in whom both tests were positive but where additional immunoglobulin clas- 
Table 1 Patients in whom both agglutination and enzyme linked direct antiglobulin tests were positive and detected the same immunoglobulin classes

\begin{tabular}{llll}
\hline No of patients & \multicolumn{2}{l}{ Direct antiglobulin test } & Comments \\
\cline { 2 - 4 } & Immunoglobulins & Complement & \\
\hline 38 & IgG & 0 & 21 haemolysing, 17 not haemolysing \\
17 & IgG & + & 13 haemolysing, 4 not haemolysing \\
1 & IgG, IgM & + & Haemolysing \\
2 & IgG, IgA & 0 & 2 haemolysing \\
1 & IgA, IgM & 0 & Haemolysing \\
2 & IgG, IgA, IgM & + & 2 haemolysing \\
\hline
\end{tabular}

Table 2 Patients in whom agglutination and enzyme linked direct antiglobulin tests were positive but additional immunoglobulin classes were shown by the enzyme linked method

\begin{tabular}{|c|c|c|c|c|}
\hline \multirow[t]{3}{*}{ No of patients } & \multicolumn{2}{|c|}{ Agglutination direct antiglobulin test } & \multirow{3}{*}{$\begin{array}{l}\text { Enzyme linked direct } \\
\text { antiglobulin test }\end{array}$} & \multirow[t]{3}{*}{ Comments } \\
\hline & \multirow{2}{*}{ Immunoglobulins } & \multirow{2}{*}{ Complement } & & \\
\hline & & & & \\
\hline 11 & IgG & 0 & $\operatorname{IgG}, \operatorname{Ig} M$ & $\begin{array}{l}9 \text { haemolysing, } 2 \text { probably not } \\
\text { haemolysing }\end{array}$ \\
\hline 11 & IgG & + & IgG, IgM & 11 haemolysing \\
\hline 1 & IgG & 0 & $\operatorname{IgG}, \operatorname{IgA}, \operatorname{Ig} M$ & Haemolysing \\
\hline 6 & IgG & + & $\operatorname{IgG}, \operatorname{Ig} A, \operatorname{Ig} M$ & 6 haemolysing \\
\hline 4 & IgG & 0 & $\operatorname{IgG}, \operatorname{IgA}$ & $\begin{array}{l}3 \text { haemolysing, } 1 \text { no longer } \\
\text { haemolysing }\end{array}$ \\
\hline 4 & IgG & + & $\operatorname{IgG}, \operatorname{Ig} A$ & $\begin{array}{l}3 \text { haemolysing, } 1 \text { no longer } \\
\text { haemolysing }\end{array}$ \\
\hline 1 & $\operatorname{Ig} A$ & + & $\operatorname{Ig} A, \operatorname{Ig} M$ & Haemolysing \\
\hline 2 & $\operatorname{IgG}, \operatorname{Ig} A$ & 0 & $\operatorname{IgG}, \operatorname{IgA}, \operatorname{Ig} M$ & 2 haemolysing \\
\hline 3 & IgG, IgM & + & $\operatorname{IgG}, \operatorname{Ig} M, \operatorname{IgA}$ & 3 haemolysing \\
\hline
\end{tabular}

Table 3 Patients in whom agglutination direct antiglobulin tests were positive only with anticomplement reagents

\begin{tabular}{lll}
\hline No of patients & $\begin{array}{l}\text { Immunoglobulins detected by enzyme } \\
\text { linked direct antiglobulin test }\end{array}$ & Comments \\
\hline 12 & IgM & 11 haemolysing, 1 could not be assessed; all cold type \\
& autoimmune haemolysis \\
6 & IgG & 2 haemolysing, 4 not haemolysing \\
2 & IgG, IgM & 2 haemolysing, 1 not haemolysing \\
2 & IgG, IgA, IgM & $\begin{array}{c}10 \text { not haemolysing; 1 haemolysing, cells had reduced I } \\
\text { status; all had cold auto and pan antibodies }\end{array}$ \\
\hline
\end{tabular}

Table 4 Patients in whom agglutination direct antiglobulin tests were negative but enzyme linked tests were positive

\begin{tabular}{lll}
\hline No of patients & $\begin{array}{l}\text { Immunoglobulins detected by enzyme } \\
\text { linked direct antiglobulin test }\end{array}$ & Comments \\
\hline 4 & IgM & 3 haemolysing (IgM autoantibodies warm reacting in 2 \\
cases); 1 not haemolysing \\
8 & IgG & 3 haemolysing, 5 not haemolysing \\
3 & IgA, None haemolysing \\
1 & IgG, IgA, IgM & No longer haemolysing \\
\hline
\end{tabular}

ses were shown by the enzyme linked method (Table 2).

3 Thirty three patients in whom the agglutination DAGTs were positive only with anticomplement reagents (Table 3 ).

4 Sixteen patients in whom agglutination DAGTs were negative but enzyme linked tests were positive (Table 4).

5 Sixty six patients in whom both agglutination and enzyme linked DAGTs were negative. Sixty one patients had no evidence of haemolysis. In the other five the haemolysis was not autoimmune in origin but was due to paroxysmal nocturnal haemoglobinuria, disseminated intravascular coagulation, or the cause was not definitely known.

\section{Discussion}

The value of enzyme linked techniques for direct antiglobulin testing is well illustrated by the present study. The methods are simple and can easily be incorporated into the routine workload of a laboratory; the reagents are stable and have a long shelf life. Enzyme linked DAGTs are more sensitive than 
agglutination tests and can detect the small amounts of $\operatorname{IgG}, \operatorname{IgA}$, and IgM which are normally present on red cells. ${ }^{4}$ Although the results of the enzyme linked tests are reported as positive or negative in this paper, linear regression analysis comparing optical density (y) with an established quantitative radioimmune assay $(x)$ showed a close correlation over the range 50-1800 molecules of IgG per red cell $(y=0.1984+0.001098 x ; r=0.956 ; p<$ $0.001 ; n=26)$. This indicates that the enzyme linked methods were quantitative, at least for IgG. The enzyme linked DAGT was positive when more than 100-120 molecules of IgG were bound per red cell.

A striking feature is the presence of increased amounts of immunoglobulins of more than one class on many patients' red cells (Tables 1-4). Assessing the degree of haemolysis in individual patients on clinical and laboratory grounds, it appears that the different immunoglobulin classes can act synergistically in causing red cell destruction and that this effect is evident even with amounts too small to be detected by the agglutination DAGT.

Although it is not uncommon to find immunoglobulins of more than one class on red cells of patients with active haemolysis, ${ }^{6-8}$ a synergistic effect on red cell destruction does not appear to have been considered previously. This is surprising because such an effect is well known for complement components, ${ }^{,}$and in vitro secretory IgA significantly augmented IgG induced antibody dependent cellular cytotoxicity. ${ }^{10}$ Also mixed type autoimmune haemolysis, where both warm IgG and cold IgM autoantibodies are present, tends to be severe, ${ }^{11}$ and the development of active haemolysis in patients taking $\alpha$-methyldopa has been attributed to the additional presence of small quantities of complement fixing IgM antibodies. ${ }^{22}$

The increased sensitivity of the enzyme linked DAGT over agglutination tests is also shown by the cases in Tables 3 and 4 . In several instances cell bound immunoglobulin was found in patients who had apparently recovered from autoimmune haemolysis. Other cases fitted into the Coombs test negative type of autoimmune haemolytic anaemia. ${ }^{13}$ Two patients in this group had autoantibodies of the rare warm reacting IgM type ${ }^{14}$; these antibodies were apparently non-complement fixing and were thought to be monomeric in configuration. Both patients had profound haemolysis which responded well to treatment with prednisolone.

Twenty three patients with predominantly cold reacting auto and pan antibodies and complement coating of their red cells could be conveniently divided into two groups depending on whether IgM was also shown on their cells (Table 3). The presence of IgM correlated well with active haemolysis; the one exception was unusual in that the red cells had reduced I status.

The red cell bound immunoglobulins detected only by the enzyme linked methods were shown to be erythrocyte antibodies by their ability to rebind to normal red cells after elution from the patient's cells; concentrated eluates from normal pooled $\mathrm{O}$ cells consistently gave negative results. High concentrations of plasma immunoglobulins may result in non-specific absorption on to red cells, and in three patients with myeloma immunoglobulins of the same class and light chain type as the serum paraprotein were detected on the red cells by the enzyme linked DAGT. These immunoglobulins, however, could not be reattached to normal red cells after elution.

We thank Dr AH Merry for assistance with the radioimmune assays, $\mathrm{Mr}$ AS Lawson for the linear regression analysis, Dr W Wagstaff for helpful advice, and Mrs P Burke for secretarial assistance.

\section{References}

' Sokol RJ, Hewitt S. Autoimmune haemolysis: a critical review. Crit Rev Oncol Hematol (in press).

${ }^{2}$ Sokol RJ, Hewitt S, Stamps BK. Autoimmune haemolysis: an 18 year study of 865 cases referred to a regional transfusion centre. Br Med J 1981;282:2023-7.

${ }^{3}$ Leach M. A direct enzyme-linked antiglobulin test for detection of red cell autoantibodies in autoimmune haemolytic anaemia. Med Lab Sci 1984;41:232-7.

${ }^{4}$ Freedman J. Membrane-bound immunoglobulins and complement components on young and old red cells. Transfusion 1984;24:477-81.

${ }^{5}$ Merry AH, Thomson E, Rawlinson VI, Stratton F. A quantitative antiglobulin test for $\mathrm{IgG}$ for use in blood transfusion serology. Clin Lab Haematol 1982;4:393-402.

- Vos GH, Petz LD, Fudenberg HH. Specificity and immunoglobulin characteristics of autoantibodies in acquired hemolytic anemia. J Immunol 1971;106: 1172-6.

${ }^{7}$ Hsu TCS, Rosenfield RE, Burkart P, Wong KY, Kochwa S. Instrumented PVP-augmented antiglobulin tests. II. Evaluation of acquired hemolytic anemia. Vox Sang 1974;26:305-25.

${ }^{8}$ Dacie JV. Autoimmune hemolytic anemia. Arch Intern Med 1975; 135: 1293-1300.

' Kurlander RJ, Rosse WF, Logue GL. Quantitative influence of antibody and complement coating of red cells on monocytemediated cell lysis. J Clin Invest 1978;61:1309-19.

${ }^{10}$ Shen L, Fanger MW. Secretory IgA antibodies synergize with IgG in promoting ADCC by human polymorphonuclear cells, monocytes, and lymphocytes. Cell Immunol 1981;59:75-81.

"Sokol RJ, Hewitt S, Stamps BK. Autoimmune haemolysis: mixed warm and cold antibody type. Acta Haematol 1983;69:26674.

12 Lalezari P, Louie JE, Fadlallah N. Serologic profile of alphamethyldopa-induced hemolytic anemia: correlation between cell-bound IgM and hemolysis. Blood 1982;59:61-8.

${ }^{13}$ Gilliland BC. Coombs-negative immune hemolytic anemia. Semin Hematol 1976; 13:267-75.

${ }^{14}$ Szymanski IO, Huff SR, Selbovitz LG, Sherwood GK. Erythrocyte sensitization with monomeric IgM in a patient with hemolytic anemia. Am J Hematol 1984;17:71-7.

Requests for reprints to: Dr RJ Sokol, Regional Blood Transfusion Centre, Longley Lane, Sheffield S5 7JN. 